\title{
Local Law in Forest Management
}

\author{
I Wayan Rideng, I Made Minggu Widyantara, Ni Made Sukaryati Karma \\ Faculty of Law \\ Universitas Warmadewa \\ Denpasar, Indonesia \\ wyrideng@gmail.com
}

\begin{abstract}
Local laws are functioned to formulate rules as guidelines for community members to behave in their lives in their customary village areas, including in forest management. This paper analyzes local legal provisions, established in awigawig, local legal forms governing rules and procedures for managing forests. The method used is an interview with three custom village managers (prajuru adat), consisting of Village Head and two forest security officers (pecalang). The results prove that the presence of awig-awig as a local law has the potential and power to play a very effective role in preserving the forest, which is a commodity whose care is entrusted to the community. The existence of awig-awig binds and demands every member of society to uphold all the provisions in it. The results of this study provide a conclusion that local law as a law created and established by the community has a more promising positive effect on the protection of society itself and its environment, including forest areas.
\end{abstract}

\section{Keywords—local law; forest management}

\section{INTRODUCTION}

Forests are natural resources that have a strategic role in human life because forests have a fundamental function as a protection of life support systems to regulate water systems, prevent erosion, flooding, preventing sea water illustration and maintaining soil fertility. The regulation on forestry is determined by the issuance of the Law of the Republic of Indonesia Number 41 of 1999, and even as regulations to manage forests are very important, the Government views the Law of the Republic of Indonesia Number 18 of 2013 on Forest Prevention and Destruction needs to be issued. The birth of the Law is based on considerations as contained in the 1945 Constitution, Article 33 paragraph (3) [1]. In the provisions of Article $18 \mathrm{~b}$ of paragraph (2) the recognition of the existence of "customary law community", from various groups of people who have original composition existing within the territory of the Republic of Indonesia has been regulated. As indigenous and tribal peoples, every society must recognize the existence of customary law in the rules of life as a nation and a state. The existence of traditional village (pakraman) and its traditional rights are recognized by the state, among them including having made awig-awig, conducting its own government and solving legal problems in its territory [2].

Efforts to preserve forests are an important part of keeping the environment as well as possible. Therefore, villagers of indigenous villages in Bali are aware that they have direct limitations to the forest, are obliged and take an active role in maintaining the irresponsible attitude and behavior of the society (krama) under the pretext of covering their economic and survival needs. Concrete manifestation of the preservation of village forest is contained in awig-awig created in written form. In awig-awig, these rules as the guidelines of every individual's life to behave in life in his society have been formulated. According to Surpha, awig-awig is a provision regulating the etiquette of social life in society to realize steady rules of each of individual's life in society [3]. Awig-awig traditional villages constitute the whole law governing the way of life for customary villagers along with their sanctions and implementing rules. In addition, awig-awig also serves to integrate the citizens in unity living together in tandem and arms. The customary village of awig-awig is a reflection of the soul of a society, religiously characterized. The cornerstone of its enforcement is the awig-awig philosophy of the traditional village of Tri Hita Karana (three sources of welfare).

Furthermore, the technical crucial role of awig-awig is to bind the community in a unity and unity of villagers to ensure cohesiveness and unity in unifying common goals to create a safe, orderly, and prosperous life in the territory of traditional villages [4]. The identification of customary village awig-awig in a positive form (written) is inseparable from the issuance of Regional Regulation (Perda) of Bali Province No. 03 of 2001 on Pakraman Village. The presence of awig-awig is expected to regulate and control citizens. The era of globalization today is marked by the rapid development of science and technology that bring adverse impact on the culture of community law and the wisdom of legal functionaries in implementing the law. In fact, in essence the existence of customary law is expected to form the identity of the local people's social life itself. Customary Law embodies a real legal feeling for the society, and continues to grow in the lives of the society themselves [5].

In maintaining the effectiveness of the awig-awig power in the midst of the dynamic era of the globalization era, all rules imposed on society to govern their lives in the state, all rules are always measured from the question of "the basis of enforceability". In this connection, the basic understanding of the importance of obeying the law for society can be maintained in the rules as measured by the way society accepts the rule. There are rules of life accepted by the community because it exists and is made important by the society itself because it is perceived to provide the benefits of serenity and justice. People have an interest in this one rule is caused by a sense of acceptance of these rules for the sake of peace and order of his life. 
On the other hand, there is also a rule of life passed down by a ruler to a subordinate, in this case a member of society, as a matter of imposition, even though it is contrary to the feelings of the law of the recipient or may not be granted as legitimate. In legal science, this is known as Gezag Authority and Macht power [6].Usually the rule of law is applicable, and the regulation must have the power to be effective, whereas without power, the authors will run aground or if followed only because of the element of coercion. Starting from that theory, the solution goes back to the awig-awig and in its application there is a known concept of 'the closest order to that society', which naturally has power when it is applied as a must-have for tranquility and the arena grows from below, obeyed because it is perceived as a must-have for the tranquility and life of indigenous peoples themselves. Based on the above explanation, the study aims to determine the nature of local legal provisions in forest management and the effectiveness of local legal arrangements on village forest management.

According to Hartiman, the condition of forests that are increasingly damaged by the encroachment of irresponsible people is evidence of the unfavorable cooperation between the government and indigenous and tribal peoples [7]. Sustainable and fair forestry development can be achieved if there is a paradigm shift. The new paradigm for forestry development is a shift in orientation from forest management to resource-based management, centralized management to decentralization, and more equitable resource management. For that reason, it is clear that indigenous peoples around the forest need to be involved in the management of the forest itself, such as the mandate of the law [7]. Forest protection policies that accommodate local forestry law can increase the active participation of the community and will facilitate the government in building mass communication networks, both vertically and horizontally. The conception of forests for people in Bali is inseparable from the community's trust structures, so that the people's trust plays a key role in maintaining and preserving existing forest areas. This becomes the basis of consideration which is deemed to be regulated in the awig-awig regulation in each traditional village.

\section{A. Traditional Village (Pakraman)}

In Bali, Traditional villages are customary law community units with special features not found in other types of customary law communities. This special feature is related to the Hindu philosophical foundation in the life of indigenous people in Bali, known as the Tri Hita Karana philosophy which etymologically consists of tri (three) karana (causes) hita (happiness), Ida Sanghyang Jagatkarana (Lord the Creator), bhuana (universe), and manusia (human). With the belief of Hindus in Bali, prosperity will be achieved if the harmony of the relationship between the elements of Tri Hita Karana is formed. In the customary village life, Tri Hita Karana's philosophy is embodied in the three elements of customary village forming:

- Parahyangan that is the heaven of the village (Kahyangantiga: Pura Desa or Bale Agung, Pura Puseh and Pura Dalem) as a place of mutual worship of God Almighty;
- Palemahan, as a place of residence and a place of livelihood is a projection of the existence of bhuana that is subject to the rule of Bale Agung's territorial law;

- Pawongan namely citizens (residents) Pakraman village called kramadesa as a whole living community of Pakraman village.

The term pakraman village is set forth in the provisions of Article 1 (4) of Bali Province Regional Regulation Number 3 of 2001 concerning pakraman village. Previously, the village of pakraman referred to as a traditional village. The concept of the village community of pakraman that became the reference comes from three syllables namely; community, desa, and pakraman. The meaning of the word "community" is the collection of several families who are bound in the customary law community in order to achieve the purpose of life in the form of inner welfare which has been established together. Meanwhile, the word "desa" derived from Sanskrit means a territorial unity of the territory inhabited by several community groups that are subject to local territory. Meanwhile, the word "pakraman" derived from Sanskrit is also a word that refers to a collection of people who inhabit a particular region and bind themselves in an agreed community of law.

Awig-awig are all provisions made by the 'customary village' community karma, used as a guide in implementing Tri Hita Karana. Awig-awig generally regulates the rights and obligations of the pakraman village community. It contains advice, bans, as well as tough and forceful sanctions. An awigawig contains the name of the traditional village, custom village boundaries, legal basis and purpose, membership terms, also contains additional transitional rules. Since awig-awig regulates the basic provisions, as a condition of its implementation which can execute a decision is established also in the form of a pararem. Awig-awig and perarem have a magical religious character, so it is highly upheld by indigenous community communities. With this basic awigawig traditional villages are tied or regulated in order to realize the purpose of life that is to ensure a sense of security, orderly, serene, and prosperous.

The term awig-awig originated from the word "wig" which means damaged. Then get the prefix "a" which means no. Thus awig-awig has the meaning of undamaged or something that becomes good. This conception is poured into the rules, both written and unwritten, giving rise to an understanding, namely awig-awig is a guideline of the way of life of the community which contains the rules for living together for the karma village in the its traditional village, to realize a life secure, peaceful, orderly and prosperous in the traditional village. Its existence brings about the function to organizing and controlling the behavior of citizens in their social life in order to achieve orderliness and tranquility of the community.

\section{METHOD}

This paper is conducted using qualitative research with an empirical juridical approach. Data were obtained through interviews conducted with traditional village officials (Perbajo Adat), Perbekel (Kepala Desa) and forest security officers (Pecalang). This study aims to obtain implications for the 
effectiveness of awig-awig implementation in conjunction with forest management, especially village forest. For then the obtained field data is processed and presented in a descriptive analysis.

\section{RESULT AND DISCUSSION}

\section{A. The Role of Traditional Villages on the Village Forest Management}

An authority of forming the rules itself is an authority born from the form of power (original). The authority is born from the innate nature that has been brought since the agreement of the existence of the community and acknowledged as a unity of the legal community that takes care of its own interests (autonomy). Such matters can be classified into the respective affairs of each community and the affairs of the common interest in the community. All these affairs are delegated to the traditional village which then becomes his affair. Regarding the matters which are the responsibility of the customary village community, the provisions are governed by customary village rules called awig-awig, which at least contain and regulate the names, territories, legal basis, objectives and terms of membership, community, types of violations and sanctions, as well as transitional/additional rules.

The existence of forest in the village area is part of the governance of each village customary village, in addition to the existence of parhyangan and pawongan policies. By awigawig in each of its customary villages governing village forest management, the active role of indigenous villages in preserving the forest is shown. In general, the process is done through a general meeting (paruman agung) citizens (krama) the community concerned. The forum is the highest forum in indigenous villages in every time to make decisions of the traditional village strategy for the Balinese community. The overall result of the agreement has been reached, included in the content of awig-awig material. Then, the results of its practical results bind the residents (krama).

\section{B. Effectiveness of Awig-awig}

The effectiveness of the rules in awig-awig closely related to the effectiveness of the existence and application of governmental laws, even for the assurance of peace and welfare of the people's lives, awig-awig has a promising level of effectiveness. Kelsen claims that the validity of the law implies that legal norms bind that people should act in accordance with those required by legal norms, namely that every citizen must establish and obey the legal norms. So the effectiveness of the law is measured from the level of obedience and compliance of members of society to uphold him as a guide that governs their behavior [8]. Furthermore, Soekanto said that the legal effectiveness is determined by five factors, namely: Factor of law itself; law enforcement factors; factor of facilities; community factors; and cultural factors [9]. Grounded on this, in relation to awig-awig establishing laws for village forest management implies that indigenous villagers need a rule to create a harmonious atmosphere in their lives. The rule is awig-awig that animates from the state of all residents (krama) and functioning ideally because it embraces ideology that has element of justice, law and benefit.
Normally, we often find that in society, the laws that have been made are ineffective. According to Pasamai, the issue of the effectiveness of law has a close relationship with the problems of implementation, implementation and law enforcement in the community for the achievement of legal objectives [10]. The establishment of awig-awig as the real rules governing the relationship between the villagers and guide the various arrangements of habits and behaviors in the social life that are considered appropriate and regulate the rights and obligations of customary village members and administrators (prajuru). Awig-awig gives everyone a socially reward when he has done his duty on it and imposed a fixed sanction if he has violated it.

Adoption of customary sanctions is basically intended for the management of village forests to be effective. The basic idea of the need for traditional villages within the management of forests in the village areas is based on the idea of applying customary sanctions for the sake of the peaceful life attainment for the society. Although there are several stakeholders outside the traditional village who are involved in forest management, basically the provisions in awig-awig made by customary villages are their own autonomous authority. In this context the application of customary sanctions can be seen as an internal rule agreed upon by the member of society in paruman (a forum).

The idea behind the thought of good law is the decision to establish rules that are in accordance with living law in a society that is certainly a reflection of the values prevailing in that society. Thus, the legal norms concerning the autonomy of pakraman village must be in accordance with the growing needs of the society, and not in contradiction with the cultural philosophy, as stated by Unger, "The Ideals of Law is rooted in the particular social life" [11]. Discussing about the effectiveness of the Law means reviewing the rules of law that meet the requirements of juridical, sociological and philosophical. These three conditions are described as follows [12]:

- The law rules that is philosophically applicable is in accordance with the ideals of law as the highest positive value.

- The rule of law that applies sociologically that if the rule is effective, it means that the rule can be enforced by the authorities even if not accepted by citizens (power theory), or the rule is valid because of the recognition of the community.

- The rule of law that is juridically applicable, is if its determination is based on a higher-level or established rule on the grounds it has established.

Further Windia says that almost there is no pakraman villages in Bali have escaped the creation/writing of awig-awig. Even in his confirmation of "pasupati". Furthermore the meaning of pasupati is meant a ceremony which according to Hinduism in the form of; pangulap, pangurip, and pemelaspas at once done [13]. Thus the content of awig-awig contains religious magical powers. Nevertheless, basically the awigawig power binds the villagers since the agreement to implement the intended content of the awig-awig is enforced. 
But with the existence of pasupati activity and endorsement by Regent/Mayor, its own strength and belief for indigenous villagers growing and developing.

The extent to which empirical evidence of the introduction of awig-awig as a local law that guides the society in carrying out his life, especially the provisions relating to the rules of forest management in the village, synthesis can be drawn that is the level of forest destruction caused by the act of villagers (krama) villagers irresponsible customs can be minimized because it is believed that a violation of awig-awig has sanctions not solely committed once at a time of violation but will be increased and this local law also has a niskala value, i.e., it is based on "restoration of balance", so that harmony the life of the residents is promising.

\section{CONCLUSION}

Based on the above explanation, the role of indigenous villages in Bali in maintaining the village forest area is to establish through awig-awig functioning very effectively because it is very adhered to and upheld by the community. The establishment of art in the awig-awig is able to guarantee the sustainability of the forest in an effort to manage it.

\section{ACKNOWLEDGEMENT}

The author would like to thank all the parties who have helped and contributed in the writing of this article, both those who contribute in the form of funding and critical ideas. Hopefully this paper can be useful theoretically and practically for the addition and development of knowledge, especially in the field of legal science.

\section{REFERENCES}

[1] PKPS, Kumpulan Peraturan Perhutanan Sosial, 2016. Direktorat Penyiapan Kawasan Perhutani Sosial. Dirjen Perhutani Sosialdan Kemitraan Lingkungan. Menhut LH RI. p.83

[2] Sudantra, I. K., Arranging the Migrants in Awig-Awig Desa Pakraman. Pyramid. Denpasar. 2008.

[3] Surpha, I. W., Regarding Desa Pakraman and Adat Bali, Pen. Bali Post.Denpasar. 2004.

[4] Parimartha, I. G., Understanding Indigenous Villages and Pakraman Village.University of Udayana Press, Denpasar. 2003.

[5] Koesnoe, H. M. Customary Law as a Model of Law. Bandung, Bandar Maju.

[6] Artadi, I. K., Bali Customary Law, With Various Problems, Pustaka Bali Post, Denpasar. 2007.

[7] Andri, H. H., "Automatic Spontaneous Adherence to Customary Law of Case

[8] H. Kelsen, in digilab unila.ac.id. accessed on January 21, 2018.

[9] S. Soerjono, Factors Affecting Law Enforcement. Jakarta: PT Raja Grafindo Persada. 2008

[10] I. Idrus, Efektivitas Hukum, http://ilhamidrus.blogspot.com/2009/06/ artikel-efektivitas-hukum.html xAccessed on January 21, 2018.

[11] S. Raharjo, Hukum Progresif, Sebuah Tawaran, Jakarta: Jentera, Edisi ke dua, 2003. p,. 62.

[12] H. Zainuddin, Filsafat Hukum, Jakarta: Sinar Grafika, 2006, p. 94.

[13] Windia, P. I. W., Danda Pecamil Popular Notes The Legal Terms of Bali, Denpasar, Upada Sastra, 2004. 